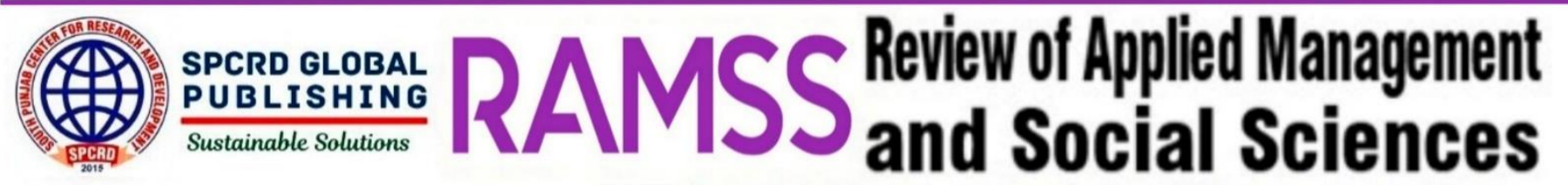 \\ Journal homepage: http://ramss.spcrd.org \\ ISSN (Print): 2708-2024 \\ ISSN (Online): 2708-3640
}

\section{CEO Overconfidence and Corporate Investment: Moderating Role of Corporate Governance Practices}

\author{
Muhammad Sadiq Shahid ${ }^{a}$, Usman Shahid \\ a Associate Professor Department Of Commerce Bahauddin Zakriya University Multan sshahidmalik@bzu.edu.pk \\ b Mphil Scholar, Bahauddin Zakriya University Multan, usman1569o@gmail.com
}

\begin{tabular}{|c|c|}
\hline ARTICLE DETAILS & ABSTRACT \\
\hline History: & \multirow{9}{*}{$\begin{array}{l}\text { This paper examines the relationship between CEO overconfidence, corporate } \\
\text { investment and firm performance along with moderating effect of corporate } \\
\text { governance (CG) between them. We collected the data of Pakistani listed firms } \\
\text { from 201O-2O18. The findings suggest that the relationship between CEO } \\
\text { overconfidence and corporate investment is significant and the corporate } \\
\text { governance also moderates the relationship of CEO overconfidence and } \\
\text { corporate performance. In addition, the authors report a significant } \\
\text { substantial relationship exists between Tobin's } Q \text { and CEO overconfidence and } \\
\text { between ROA and CEO overconfidence. The moderator effect is also significant } \\
\text { in the case of CEO overconfidence and Tobin's Q, and in case of ROA and CEO } \\
\text { overconfidence. This is the first empirical paper on CEO overconfidence, } \\
\text { corporate investment and governance practices using data for the Pakistan. }\end{array}$} \\
\hline 20 & \\
\hline 2020 & \\
\hline Key & \\
\hline$C E$ & \\
\hline Inve & \\
\hline Performance, Corp & \\
\hline Governance & \\
\hline EL & \\
\hline
\end{tabular}

DOI: $10.47067 /$ ramss.v3i1.23

(C) 2020 The authors. Published by SPCRD Global Publishing. This is an open access article under the Creative Commons Attribution-NonCommercial 4.o

Corresponding author's email address: sshahidmalik@bzu.edu.pk

\section{Introduction}

Following the crash of stock market in 2007-2008 crises, firms have implemented regulations to control the irrational behavior of CEOs in investment decisions. During the past two decades, CEOs have been involved in expansion of their respective companies through acquisitions and mergers. Although the purpose of M\&A activities is to increase shareholder's wealth; CEOs of major companies have invested in worthless a company which has resulted in loss of value for shareholders. This behavior is due to the overconfidence of the CEOs of large companies. CEO overconfidence is related to the corporate and behavioural finance and is the center of attention for many researchers. The CEO overconfidence refers to the characteristic of the CEOs to overestimate the expected returns of companies. Malmendier and Tate (2005) used divestment behavior of CEOs to measure the overconfidence. According to Malmendier and Tate (2005), overconfident CEOs overestimate expected returns and fail to divest money from such investments which results in loss of value for the shareholder's wealth. Malmendier and Tate $(2005,2008)$ also used the net stock purchases of CEOs to classify the overconfident CEOs. 
Many researchers have identified the relationship of CEO overconfidence with the corporate investment decisions made by the company; however, they do explain the relationship of CEO overconfidence with the performance of the company. In this research, the relationship of CEO overconfidence with the corporate performance is explained. This paper focuses on the non-financial 250blisted firms on Pakistan Stock Exchange (PSX) from 2006-2017. Within this time frame, the study analyzes the relationship between CEO overconfidence and corporate performance, where corporate performance is measured by ROE, ROA, profit margin and total shareholder return based on the study of Bhagat \& Bolton (2008). The research utilizes Tobin's Q, ROA, ROE and total shareholder return to measure corporate performance because these are directly related to the shareholder's wealth. The measure that is used in this study for CEO overconfidence is the CEOs compensation and number of stocks held by CEOs (Buyl, Boone \& Wade, 2017).

There are numeral studies on corporate investment decisions in developed countries, but only limited studies are carrying out in developing economies. This research paper identifies the effect of overconfident CEOs on the corporate investments of the firms in Pakistan. Most of the firms listed on the PSX started as a family business and most of the CEOs are also the majority shareholders, it is necessary to see whether their ownership rights affect the investments of the firms or not. The diversification decisions of a company show the overconfidence of CEOs in their own abilities and future returns of their companies.

Many research studies have already examined the connection of overconfident CEOs and investment decisions (Lin, Hu \& Chen, 2005; Malmendier\& Tate, 2005; Cao, 2011; Jiang, Liu \& Zhang, 2010; Ham, Seybert\& Wang, 2017); however, the previous literature has been unable to effectively indentify the impact of CEO overconfidence on corporate investment and firm performance. Especially in the developing markets such as Pakistan, it is very important to investigate about CEO overconfidence, corporate investment, and corporate performance.

The primary objective of this paper is to discover how CEO overconfidence influences the corporate investment decisions of the firm. The second objective is to identify the impact of CEOs overinvestment on corporate performance. Apart from the above given objective, this research has following objectives:

- To identify the relationshipbetween CEO overconfidence, corporateinvestmentdecisions and the corporate performance.

- To identifywhethercorporategovernancemoderates the relationshipbetween CEO overconfidence and corporateinvestment

- To identifywhethercorporategovernancemoderates the relationshipbetween CEO overconfidence and corporate performance

Further, to achieve the objectives of study, this research answers the following research question

- Whatis the relationshipbetween CEO overconfidence,corporateinvestmentdecisions andcorporate performance?

- How corporategovernancemoderates the relationship of CEO overconfidence and corporateinvestment?

- How corporategovernancemoderates the relationship of CEO overconfidence and corporate performance?

The major objective of paper is to examines whether CEOs overconfidence affects the investment 
decisions of corporations. Another goal of this research study is to determine whether CEOs overconfidence is good or bad for the corporate performance. As these objectives can serve both academically as well as for industry, and have some implications in both academics as well as in industry.

Academically, this research work broadly contributes towards the existing literature available on the topic of behavioral finance. The research specifically adds toward the literature on CEO overconfidence and its influence on the business's performance. The research study utilizes corporate governance as a moderator to check how the relationship of overconfident CEOs and corporate performance is changed. This not only clarifies the impact of CEO overconfidence on corporate performance but also tends to glorify the importance of corporate governance in controlling CEOs risky investments.

This thesis utilizes CEO overconfidence to indicate whether there is an increase in the investment level of corporations or not. Investments play a key role in the growth of the company which is why it is of utmost importance in financial literature. This research thesis provides evidence that overconfidence of the chief executive can led to more risky investments. These risky investments can adversely affect the company's profits. However, this research also provides enough evidence that corporate governance can be used to restrain CEOs from overinvesting in risky projects. Although, corporate governance and performance have already been tested before; this research will give a new direction to already available studies on corporate governance and firm performance in the presence of overconfident executives. The research also contributes towards the influence of firm age, firm size, cash flow sensitivity and the firm's growth on the firm performance and the firm's investment decisions. Academically, this research will also serve as a guiding force for new researchers and serve as a research gap for new research studies.

Further, this research will provide insights into the inefficient corporate investment decisions that are made by over-optimistic CEOs. This research study also provides a way for the directors to increase the corporate performance using the corporate governance to restrain CEOs power in the investment decisions. Although, corporate governance was previously used to minimize risks; this research provides insights on how the corporate governance can be used to limit CEOs overconfidence and to increase the efficiency of corporate investments. The research also explains the role of firm size and firm age in corporate performance. From the findings of the research, it is evident that a firm's size and age do not play a significant role in improving the performance.

However, the firm's size plays a negative but significant role in corporate investment while firm age has no significant impact on corporate investment as well. This means corporate investments are less risky when firm size is large and vice versa. Also, directors can find out how cash flow sensitivity affects the corporate investment decisions of the firm. Managers and executives can make efficient decisions to increase corporate performance. The research also contributes towards providing insights about how the growth of the firm can affect the corporate investment decisions and corporate performance.

This paper consist of following section including introduction, section II provide the review of literature. The section III discussmethodology and section IV discussed the results and discussion. Last section provided findings and suggestions for investors in Pakistan.

\section{Literature Review}

Corporate investment is simply a way for companies to utilize their idle funds to make profit. Corporate investment is an investment that a company makes to earn profit. However, it does not mean 
to invest in every project that is available. A company should invest only in the projects that give positive net present value (Biddle et al., 2009). Investment only in the projects that give positive net present value is referred to as investment efficiency (Biddle et al., 2009).

Taylor and Brown (1988) defined overconfident investors as those investors who consider themselves 'above average' and are more confident over the returns on their investments. Benos (1998) believes that overconfident behavior is due to the overestimation of one's abilities, which result in overinvestment from people in a single entity. Malmendier\& Tate (2005) argue that overconfident managers are more likely to diversify their investments and get involved in mergers and acquisitions activities. Although, Roll (1986) was the first person to officially conduct a study on the behavior of overconfident managers and their involvement in M\&A activities; the study of Malmendier\& Tate (2005) is considered as a pioneer in identifying the behavior of overconfident CEOs. This is largely due to the measures of overconfidence used by Malmendier\& Tate (2005), that CEOs are considered overconfident if they constantly fail to decrease their personal disclosure to firm-specific risks.

The overconfident managers are more prone to inefficient investments. Deshmukh, Goel, and Howe (2013) state that overconfident managers only want to increase the market value of the venture which results in inefficient investments. Malmendier\& Tate (2005) argue that overconfident managers are more perspective to diversify their investments. In doing so, overconfident managers are more involved in acquisitions and merger decisions. Likewise, Malmendier, Tate, and Yan (2011) contend that overoptimistic CEOs think that the business is underperforming and, subsequently, lean toward not to raise outer value financing. They hold profit to back speculations and along these lines bring down profits (Deshmukh, Goel, and Howe, 2013). Over-optimistic CEOs may make acquisitions that are value destroying contrasted with CEOs that are rational.

Corporate governance is defined as, "the system of rules, practices and processes by which a company is directed and controlled" (Hart, 1995). The existing literature on the corporate governance focuses mostly on agency theory and earning management; however, role of corporate governance in restraining overconfident CEOs is not widely researched till now.

After the Sarbanes Oxley act was passed in 2002, many restrictions have been imposed on the CEOs to protect the interests of shareholders (Coates, 2007). Now, directors and shareholders can utilize the options such as block ownership, CEO stock options, outside directors, director's motivation and time devotion to restrain CEOs from overinvestment (Buyl et al., 2017).

According to Patel \& Cooper (2014), stock option plan is a paying method in which director's pay CEOs by giving them stock rewards. According to Tian \& Yang (2014) point of view, the policy of CEOs stock option plans encourage the executives to invest in projects that are highly risky and offer high returns.

Block Ownership is a monitoring device through which block holders can restrain the decision making power of CEOs (De Haan\&Vlahu, 2016). As Grove et al., (2011) argue that block owners can directly influence the decisions of the company as their holding grants them voting rights in the company. Outside directors is also an effective source for monitoring CEOs investments. According to Jensen \&Meckling (1976), boards of directors are accountable for monitoring the CEOs in today's modern corporations. Carter et al. (2003) argue that a more diverse board is the one that has more outside directors. Choi et al. (2007) concluded that independent directors are in a better position to monitor and control the decisions of CEOs. 
Director's time devotion refers to whether the director gives the prerequisite time to the company or not. Buyl, Boone \& Wade (2017) suggested that director's time devotion can play a part in restraining overconfident CEOs from overinvesting. Zhu \& Chen (2015) concluded that director's that devote requisite time towards the business, control the CEOs overinvestment better than the director's that fail to devote requisite time to the business.

In this study, we utilized the above restrictions to moderate the relationship of CEO overconfidence with corporate investment and performance.

Based on the above arguments, we can hypothesize that:

H1: There is a positive relationship between CEO overconfidence and Corporate Investments H2: There is a negative relationship between CEO overconfidence and Corporate Performance.

H3: There is a negative relationship between CEO overconfidence and corporate investments when corporate governance practices are used as moderating variable.

H4: There is apositiverelationship between CEO overconfidence and corporate performance when corporate governance practices are used as moderating variable.

\section{Methodology}

Our objective of the paper is to examine the impact of CEO overconfidence on corporate performance. For this purpose, initially we select the sample of 432 non-financial listed firms on Pakistan Stock Exchange. For better results, we only took the data from companies whose data was complete and finally, we collect the data of 250 companies from 2006-2018.

We used proxies for the variables, for CEO overconfidence, we used the proxy "number of stocks held by CEOs" as done by Buyl, Boone \& Wade (2017). The data for CEO overconfidence was collected from annual reports utilizing the number of stocks held by CEOs. The firm performance measure ratios such as ROA, ROE, Tobin's Q and total shareholder return were calculated by using financial statement items. The data for corporate governance was collected from different sources. For CEO stock options, data was collected from the proxy statements of the companies as done by Buyl\& Wade (2017). For the block ownership variable, we used the shareholder's stake in firm and their ability to control CEOs decision making (Buyl, \& Wade, 2017). Grove et al., (2011) concluded that if a shareholder holds 5\% stocks of a company, he/she can influence the decisions of CEOs. For outside directors, we used the approach of Hambrick et al. (2015) that suggested that outside directors have a tendency to monitor the overconfident CEOs better than their inside counterparts. The variable director's time devotion measure by a dummy which identifies whether the director holds responsibilities in only one companywe assigned it 1, otherwise zero. Zero indicates that the director can devote requisite time while a one indicates that the director can't devote the requisite time and attention to the company. The directors' motivation, ownership stake of the director in the firm was used as a proxy as suggested by Buyl, Boone \& Wade (2017). The measures of CEO overconfidence include CEO compensation, number of stocks held by the CEO and options held by CEOs.Firm performance measures include ROE, ROA, shareholder return and Tobin's q. 


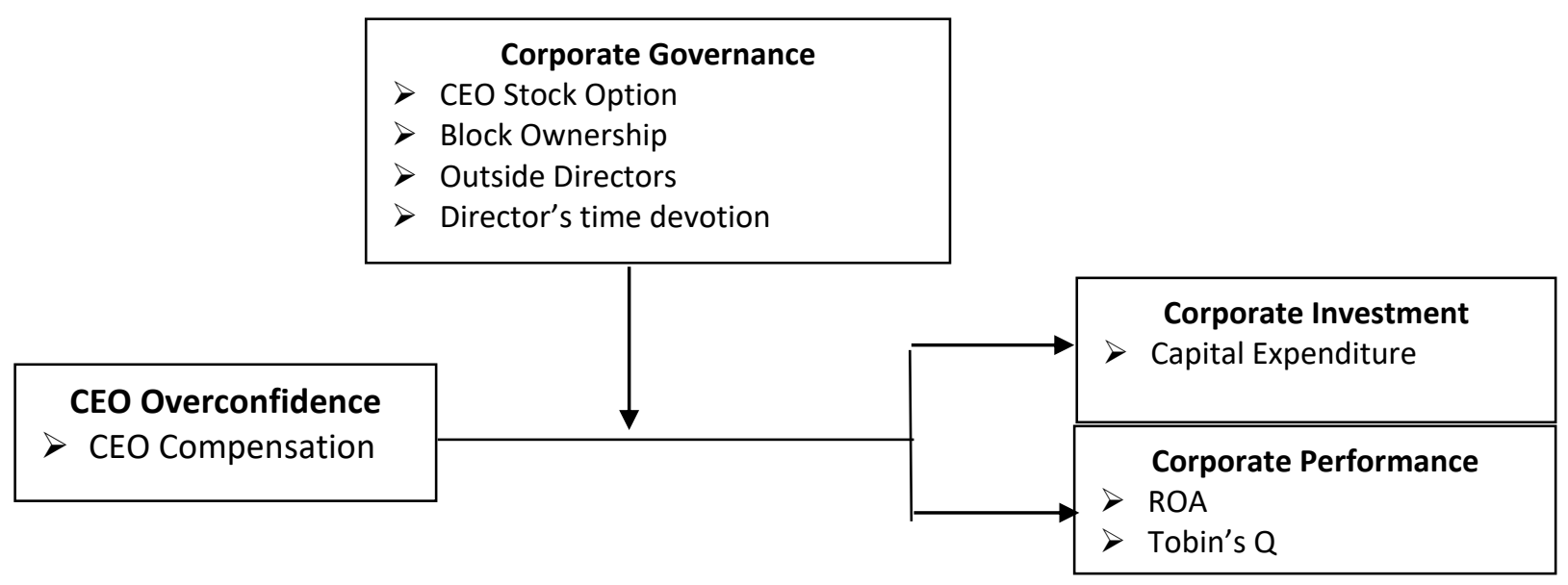

\subsection{Econometric Equation}

Centered on the existing literature (Malmendier\& Tate, 2005; Cao, 2009; Lin, Hu \& Chen, 2005; Ham, Seybert\& Wang, 2017; Huang, Jiang, Liu \& Zhang, 2011), I have estimated the following linear equations to measure the relationship of CEO overconfidence with the corporate investment decisions and corporate performance:

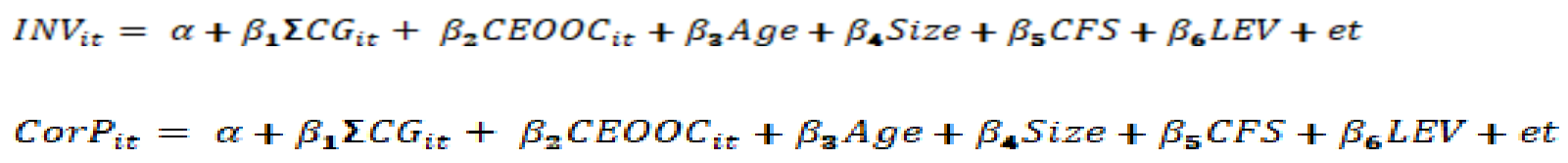

Following Buyl, Boone \& Wade (2017), we investigate the relationship between CEO overconfidence, corporate investment and performance, with moderating effects of corporate governance.

$$
\begin{aligned}
& I N V_{i t}=\alpha+\beta_{1} C E O O C_{i t} * C G_{i t}+\beta_{2} A g e+\beta_{3} \text { Size }+\beta_{4} C F S+\beta_{5} L E V+e t \\
& \operatorname{CorP}_{i t}=\alpha+\beta_{1} \text { CEOOC }_{i t} * C G_{i t}+\beta_{2} A g e+\beta_{3} \text { Size }+\beta_{4} C F S+\beta_{5} L E V+e t
\end{aligned}
$$

Where INVit is a corporate investment, CorPit is corporate performance, CEOOCit is the CEO overconfidence, CGit is corporate governance, Age is the firm age, size is firm size, CFS is cash flow sensitivity and LEV is the leverage. The definitions and measurement indicators of variables are given below:

\section{Table o1: Variable Definitions and Indicators}

\begin{tabular}{|l|l|l|l|}
\hline $\begin{array}{l}\text { Symbo } \\
\mathbf{l}\end{array}$ & Variable & Measurement indicators & Sources \\
\hline $\mathbf{I N V}$ & $\begin{array}{l}\text { Corporate } \\
\text { investment }\end{array}$ & Capital Expenditures/lagged assets (CELA) & $\begin{array}{l}\text { Malmendier\& } \\
\text { (2005) }\end{array}$ \\
\hline CorP & $\begin{array}{l}\text { Corporate } \\
\text { Performance }\end{array}$ & $\begin{array}{l}\text { Tobin's Q [(market value of equity + book value } \\
\text { of debts)/book value of total assets], ROA }\end{array}$ & Ruissen (2012) \\
\hline
\end{tabular}




\begin{tabular}{|l|l|l|l|}
\hline CG & $\begin{array}{l}\text { Corporate } \\
\text { governance } \\
\text { CEO } \\
\text { Overconfide } \\
\text { nce }\end{array}$ & $\begin{array}{l}\text { CEO Stock Option, Block Ownership, Outside } \\
\text { Directors, Director's time devotion }\end{array}$ & $\begin{array}{l}\text { Buyl, Boone \& Wade } \\
\text { CEO compensation }\end{array}$ \\
\hline Age & Firm's Age & No. of years since established & $\begin{array}{l}\text { Buyl, Boone \& Wade } \\
(2017)\end{array}$ \\
\hline Size & Firm's Size & Log Assets & $\begin{array}{l}\text { Rashid \& Nadeem } \\
\text { (2014) }\end{array}$ \\
\hline CFS & $\begin{array}{l}\text { Cash Flow } \\
\text { Sensitivity }\end{array}$ & $\begin{array}{l}\text { Cash flow to the net capital ratio } \\
\text { Javid \& Iqbal (2008) }\end{array}$ \\
\hline LEV & Leverage & Total liabilities to total assets & $\begin{array}{l}\text { Fazzari, Hubbard, \& } \\
\text { Petersen (1988) }\end{array}$ \\
\hline
\end{tabular}

To check for multicollinearity, we have used the variation inflation factor (VIF) test. The table 2 shows the VIF values of the independent variable and control variables. A general rule is that multicollinearity exists when any of the VIF value is equal to or above than 4 . In our case, all the values are below 4 which means that none of the independent and control variables are highly correlated. This means that our data is valid for further analysis.

Table o2: Variation Inflation Factor Test(VIF)

\begin{tabular}{|l|l|l|}
\hline Variable & VIF & $\mathbf{1}$ VIF \\
\hline CEOOC & 1.36 & 0.735707 \\
\hline FS & 1.36 & 0.7369 \\
\hline FA & 1.05 & 0.954302 \\
\hline CG_Score & 1.05 & 0.955013 \\
\hline LEV & 1.04 & 0.961265 \\
\hline CFS & 1.02 & 0.985118 \\
\hline Mean VIF & $\mathbf{1 . 1 4}$ & \\
\hline
\end{tabular}

After conducting the test for multicollinearity, we checked heteroscedasticity by using Breuschpagan test and tablez show the results of the Breusch-Pagan test:

Table 03: Breusch-Pagan Test of Heteroscedasticity (DV=CE)

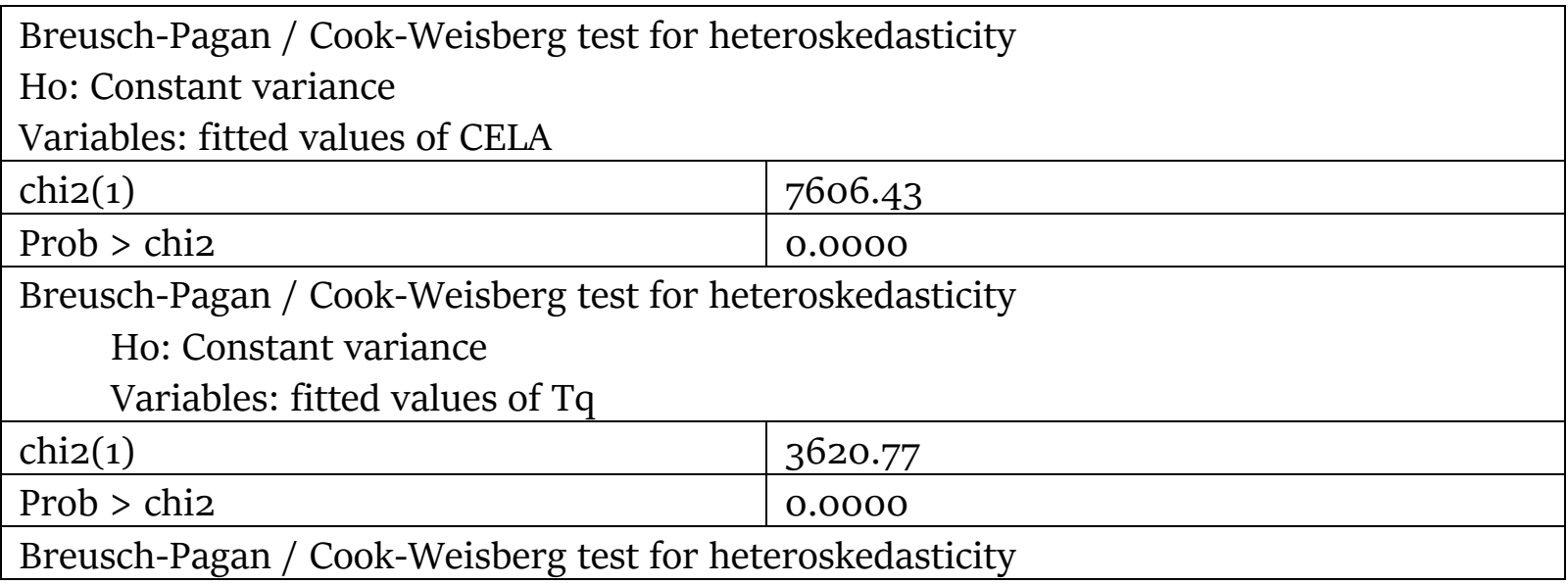




\begin{tabular}{|l|l|}
\hline \multicolumn{2}{|l|}{$\begin{array}{l}\text { Ho: Constant variance } \\
\text { Variables: fitted values of ROA }\end{array}$} \\
\hline chi2(1) & 345.21 \\
\hline Prob $>$ chi2 & 0.0000 \\
\hline
\end{tabular}

The results of heteroscedasticity test when the dependent variable is capital expenditures (CE)show that heteroscedasticity exists in the dependent variable. To control for this heteroscedasticity, robust standard error regression is used in this study. Robust standard error regression removes the problem of heteroscedasticity. The table entails the heteroscedasticity test when Tobin's $\mathrm{q}$ is used and results indicate that heteroscedasticity exists. To remove heteroscedasticity, robust standard errors regression is used. The tableo5 resultsindicate heteroscedasticity as the probability of chi $^{2}$ is 0.000 when the dependent variable is ROA. To control for heteroscedasticity, robust standard error regression is being used.

\section{Empirical Analysis and Results}

The balanced panel data is used in this study to examine the relationship between variables. The panel data random effects GLS regression has been applied and outcomes of regression with and without moderator effects are reported in table 04 :

Table 04: Pooled OLS Results

\begin{tabular}{|c|c|c|c|c|c|c|}
\hline & \multicolumn{3}{|c|}{ Without Moderator Effect } & \multicolumn{3}{|c|}{ With Moderator Effect } \\
\hline & $\begin{array}{l}\text { CE } \\
\text { Model } 1\end{array}$ & $\begin{array}{l}\text { Tobin's } \\
\text { q } \\
\text { Model } 2\end{array}$ & $\begin{array}{l}\text { ROA } \\
\text { Model } 3\end{array}$ & $\begin{array}{l}\text { CE } \\
\text { Model } 4\end{array}$ & $\begin{array}{l}\text { Tobin's q } \\
\text { Model } 5\end{array}$ & $\begin{array}{l}\text { ROA } \\
\text { Model } 6\end{array}$ \\
\hline CEOOC & $\begin{array}{l}0.0674^{* *} \\
* \\
(0.023)\end{array}$ & $\begin{array}{l}0.045^{* *} \\
* \\
(0.014)\end{array}$ & $\begin{array}{l}0.025^{* * *} \\
(0.008)\end{array}$ & & & \\
\hline CG_Score & $\begin{array}{l}-0.0109 \\
(0.025)\end{array}$ & $\begin{array}{l}-0.021 \\
(0.013)\end{array}$ & $\begin{array}{l}0.029 * * \\
* \\
(0.005)\end{array}$ & & & \\
\hline Age & $\begin{array}{l}-0.0016 \\
(0.001)\end{array}$ & $\begin{array}{l}-0.001 \\
(0.001)\end{array}$ & $\begin{array}{l}-0.0001 \\
(0.0002)\end{array}$ & $\begin{array}{l}-0.035 \\
(0.001)\end{array}$ & $\begin{array}{l}-0.009 \\
(0.001)\end{array}$ & $\begin{array}{l}-0.089 \\
(0.002)\end{array}$ \\
\hline FS & $\begin{array}{l}-0.050^{* * *} \\
(0.019)\end{array}$ & $\begin{array}{l}0.012 \\
(0.012)\end{array}$ & $\begin{array}{l}0.006 * * \\
(0.003)\end{array}$ & $\begin{array}{l}- \\
0.049 * * * \\
(0.018)\end{array}$ & $\begin{array}{l}0.013 \\
(0.012)\end{array}$ & $\begin{array}{l}0.006 * * \\
(0.003)\end{array}$ \\
\hline CFS & $\begin{array}{l}0.063^{* * *} \\
(0.001)\end{array}$ & $\begin{array}{l}0.041^{* * *} \\
(0.002)\end{array}$ & $\begin{array}{l}0.025^{* *} \\
(0.0002)\end{array}$ & $\begin{array}{l}0.013^{* * *} \\
(0.001)\end{array}$ & $\begin{array}{l}0.001^{* * *} \\
(0.0003)\end{array}$ & $\begin{array}{l}0.034^{* *} \\
(0.0002)\end{array}$ \\
\hline LEV & $\begin{array}{l}0.9570^{* *} \\
* \\
(0.209)\end{array}$ & $\begin{array}{l}0.862 * * \\
* \\
(0.065)\end{array}$ & $\begin{array}{l}-0.019 \\
(0.013)\end{array}$ & $\begin{array}{l}0.959^{* * *} \\
(0.207)\end{array}$ & $\begin{array}{l}0.865^{* *} \\
* \\
(0.064)\end{array}$ & $\begin{array}{l}-0.020 \\
(0.014)\end{array}$ \\
\hline constant & $\begin{array}{l}0.5960^{* *} \\
(0.248)\end{array}$ & $\begin{array}{l}0.385^{* *} \\
* \\
(0.110)\end{array}$ & $\begin{array}{l}-0.058^{* *} \\
(0.029)\end{array}$ & $\begin{array}{l}0.557^{* * *} \\
(0.210)\end{array}$ & $\begin{array}{l}0.323^{* * *} \\
(0.097)\end{array}$ & $\begin{array}{l}0.006 \\
(0.024)\end{array}$ \\
\hline CEOOCCG & & & & $\begin{array}{l}0.028 * * * \\
(0.010)\end{array}$ & $\begin{array}{l}0.019 * * * \\
(0.0061)\end{array}$ & $\begin{array}{l}0.011^{* * *} \\
(0.003)\end{array}$ \\
\hline
\end{tabular}

Note: $C E O O C=C E O$ compensation (measure for CEO overconfidence); CG_Score is Corporate 


\section{Governance}

Score, FS=Firm's Size, CFS= Cash Flow Sensitivity, LEV= Leverage and CEOOCCG is the interaction term of

CEO Overconfidence and Corporate Governance Score. CE; Capital expenditure and ROA; Return of Assets

In table4, the model1 results show that the p-value for CEO overconfidence is less than 0.05 which specifies that a significant relationship exists between ccorporate investment and CEO overconfidence. The results also indicate that corporate governance and firm's age had a negative and insignificant relationship with capital expenditure (corporate investment). The others control variables results show a significant relationship with the corporate investment. In these variables, CFS and leverage depict a positive relation with the capital expenditure ratio while firm's size has a negative association. This means as the firm's size increases, its capital expenditures to lagged assets decreases. This, in turn, implies that corporate investments decrease when a firm's size is large and vice versa.

The results of model 2 show that there exists a significant relationship amidst Tobin's Q and CEO compensation. It implies that CEO overconfidence has a significant effect on the company's performance. Corporate governance, firm's age, and firm's size show an insignificant relationship with the corporate performance of the firm as their p-value is more than 0.5. The variable cash flow sensitivity and leverage also have a significant relationship with corporate performance. Similarly, the Model 3results also indicating a significant relationship exists between ROA and CEO overconfidence. Other variables such as firm size, corporate governance, and CFS has a positive relationship with ROA.

The Model 4results shows a significant relationship between the corporate governance has some significant effect on the affiliation of CEO overconfidence and corporate investment. The p-value of firm age is higher than 0.05 indicating an insignificant relationship with corporate investment. All other control variables have a significant relationship with the corporate investment. All control variables except Firm size and firm age portray a positive relation with the dependent variable when CG practices are incorporated in the firm. Firms' size has a significant but negative relation with corporate investments which means that if the relationship is negative, small firms make large investments and large firms make small investments.

The results of Model 5 indicates that the p-value of the interaction term of CEO overconfidence and corporate governance is 0.001 which is below 0.05 which displays that a significant relationship is present between Tobin's q and the interaction term of CEO overconfidence and CG Score. This implies that corporate governance has some moderation effect on the relationship of corporate performance and executive overconfidence. The control variables being the firm's size and age have an insignificant relationship with the corporate performance while all other variables show a significant association with firm's performance.

In table 4, the model 6 results also indicate that the p-value of CEO Overconfidence when corporate governance moderates the relationship is below 0.05. This indicates a significant relationship between corporate investment and the interaction term of CG score and CEO overconfidence. This implies that corporate governance has a significant impact on the relationship that exists between corporate performance and CEOOC (CEO overconfidence). Firm's age and leverage have an insignificant relationship with corporate performance while all other control variables have a significant relationship 
with the corporate performance. Firms' age coefficient is a negative value which means that a firm's age negatively relates to the profitability of the firm. As the firm's age increases, the profitability decreases; however, because the results are insignificant, this cannot be proved.

\section{Discussion and Conclusion}

The aim of this paper is to examine the impact of executive overconfidence on corporate investment decision as well as firm's performance. Further examine whether corporate governance serves as a moderating variable between CEO's overconfidence and corporate investment and also between the CEO overconfidence and the business's performance. We employed two dependent variables of corporate performance and corporate investment, and both variables are somewhat affected by the policies of the CEOs. The overconfident CEOs tend to increase the corporate investments and thus, in turn, increase the corporate performance. However, overconfidence can also cause the CEOs to have an adverse effect on corporate performance when CEOs invest in riskier investments.

The first hypothesis of our study devised that a significant relationship is existent between CEO overconfidence and corporate investment. The findings of the dataset indicate that there is a significant relationship that exists between the corporate investment and CEO overconfidence. This means that we can accept this hypothesis. While the second hypothesis examine whether a significant relationship exists between CEO overconfidence and corporate performance. The results suggest that a significant relationship indeed exists between CEO overconfidence and company's performance. Similarly, when we applied regression on the dataset containing ROA as a measure for performance, the results indicated that there exists a significant relationship between CEO overconfidence and corporate performance.

On the basis of these results, we cannot reject the hypothesis 2 and therefore, it stands true that there is a significant impact of CEOs overconfidence/over-optimism on the firm's performance.

The third hypothesis was to test the moderating role of corporate governance in restraining CEO overconfidence and corporate investment. For moderation effect, the interaction between the variables CEO overconfidence and corporate governance were used. The regression table predicted that the findings are significant.

The interaction term portrays a significant impact on the corporate investment. This means that our hypothesis that there exists a negative relationship amongst corporate investment and CEO overconfidence when corporate governance practices are used cannot be rejected. The coefficient of CEOOCCGScore is less than the co-efficient of CEOOC which specifies the moderating behavior of corporate governance. The third hypothesis stands true as CG practices restrain overconfident CEOs from huge investments.

The fourth hypothesis was to test whether corporate governance moderates the relationship between CEO overconfidence and corporate performance. As this research study utilizes two different measures for the corporate performance, separate tests were applied to find the results. The interaction term CEO overconfidence * CG_Score was used for the moderation effect.

The results of the first dataset where Tobin's q serves as a dependent variable show a significant relationship with the independent variable. This indicates that corporate governance works as a moderator between corporate performance and CEO overconfidence. The results provide evidence that our fourth hypothesis stands true. 
Similar results were seen when we applied the regression on the dataset where ROA works as an indicator of corporate performance. The dataset demonstrates that there exists a significant relation between the company's performance and CEO overconfidence. On the basis of these results, it is not possible to reject the fourth hypothesis.

Based on the above limitations, recommendations for the future research are made. This research contains data only from non-financial firms listed on PSX while the results from the financial firms are not discussed. Future researchers can look at the financial firm's data to find the relationship between CEO overconfidence and corporate investment/performance.

Future researches can also utilize more corporate governance variables such as director's motivation, protection of minority ownership rights, legal framework, and relationship with stakeholders, and transparency in financial reporting. Another aspect that future researchers can look at is to use a different measure for the CEO overconfidence. The total number of stocks and options held by CEOs can also be used as a measure for CEO overconfidence.

\section{References}

Benos, A. V. (1998). Aggressiveness and survival of overconfident traders. Journal of Financial Markets, 1(3-4), 353-383.

Bhagat, S., \& Bolton, B. (2008). Corporate governance and firm performance. Journal of corporate finance, 14(3), 257-273

Biddle, G. C., Hilary, G., \& Verdi, R. S. (2009). How does financial reporting quality relate to investment efficiency?. Journal of accounting and economics, 48(2-3), 112-131.

Buyl, T., Boone, C., \& Wade, J. B. (2017). CEO narcissism, risk-taking, and resilience: An empirical analysis in US commercial banks. Journal of Management, 0149206317699521.

Cao, J. (2011). CEO overconfidence or stock mispricing and growth? Reexamining the effect of CEO option exercise behavior on corporate investment.

Carter, D. A., Simkins, B. J., \& Simpson, W. G. (2003). Corporate governance, board diversity, and firm value. Financial review, 38(1), 33-53.

Choi, J. H., \& Wong, T. J. (2007). Auditors' governance functions and legal environments: An international investigation. Contemporary Accounting Research, 24(1), 13-46.

Coates, I. V., \& John, C. (2007). The goals and promise of the Sarbanes-Oxley Act. Journal of Economic Perspectives, 21(1), 91-116.

De Haan, J., \&Vlahu, R. (2016). Corporate governance of banks: A survey. Journal of Economic Surveys, 30(2), 228-277.

Deshmukh, S., Goel, A. M., \& Howe, K. M. (2013). CEO overconfidence and dividend policy. Journal of Financial Intermediation, 22(3), 440-463.

Grove, H., Patelli, L., Victoravich, L. M., \& Xu, P. (2011). Corporate governance and performance in the wake of the financial crisis: Evidence from US commercial banks. Corporate Governance: An International Review, 19(5), 418-436.

Ham, C., Seybert, N., \& Wang, S. (2018). Narcissism is a bad sign: CEO signature size, investment, and performance. Review of Accounting Studies, 23(1), 234-264.

Hart, O. (1995). Corporate governance: some theory and implications. The economic journal, 105(430), 678-689.

Huang, W., Jiang, F., Liu, Z., \& Zhang, M. (2010). Agency cost, top executives' overconfidence, and investment-cash flow sensitivity-Evidence from listed companies in China. Pacific-Basin Finance Journal, 19(3), 261-277. 
Jensen, M. C., \&Meckling, W. H. (1976). Theory of the firm: Managerial behavior, agency costs, and ownership structure. Journal of financial economics, 3(4), 305-36o.

Lin, Y. H., Hu, S. Y., \& Chen, M. S. (2005). Managerial optimism and corporate investment: Some empirical evidence from Taiwan. Pacific-Basin Finance Journal, 13(5), 523-546.

Malmendier, U., \& Tate, G. (2005). CEO overconfidence and corporate investment. The journal of finance, $60(6), 2661-2700$.

Malmendier, U., \& Tate, G. (2005). Does overconfidence affect corporate investment? CEO overconfidence measures revisited. European Financial Management, 11(5), 649-659.

Malmendier, U., \& Tate, G. (2008). Who makes acquisitions? CEO overconfidence and the market's reaction. Journal of Financial Economics, 89(1), 20-43.

Patel, P. C., \& Cooper, D. (2014). Structural power equality between family and non-family TMT members and the performance of family firms. Academy of Management Journal, 57(6), 16241649 .

Roll, R. (1986). The hubris hypothesis of corporate takeovers. Journal of business, 197-216.

Taylor, S. E., \& Brown, J. D. (1988). Illusion and well-being: a social psychological perspective on mental health. Psychological Bulletin, 103(2), 193.

Tian, G. Y., \& Yang, F. (2014). CEO incentive compensation in US financial institutions. International Review of Financial Analysis, 34, 64-75.

Zhu, D. H., \& Chen, G. (2015). CEO narcissism and the impact of prior board experience on corporate strategy. Administrative Science Quarterly, 6o(1), 31-65. 